\title{
ROCKing regeneration: Rho kinase inhibition as molecular target for neurorestoration
}

\author{
Lars Tönges ${ }^{1}$, Jan-Christoph Koch ${ }^{1}$, Mathias Bähr ${ }^{1,2}$ and Paul Lingor ${ }^{1,2}$ * \\ 1 Department of Neurology, University Medicine Göttingen, Göttingen, Germany \\ ${ }^{2}$ DFG Research Center for the Molecular Physiology of the Brain, Göttingen, Germany
}

\section{Edited by:}

Simone Di Giovanni, University of

Tuebingen, Germany

Reviewed by:

Simone Di Giovanni, University of Tuebingen, Germany

Kazim Sheikh, The University of Texas Health Science Center at Houston, USA

\section{${ }^{*}$ Correspondence:}

Paul Lingor, Department of Neurology, University Medicine Göttingen, Robert-Koch-Strasse 40, 37075 Göttingen, Germany.

e-mail: plingor@gwdg.de
Regenerative failure in the CNS largely depends on pronounced growth inhibitory signaling and reduced cellular survival after a lesion stimulus. One key mediator of growth inhibitory signaling is Rho-associated kinase (ROCK), which has been shown to modulate growth cone stability by regulation of actin dynamics. Recently, there is accumulating evidence the ROCK also plays a deleterious role for cellular survival. In this manuscript we illustrate that ROCK is involved in a variety of intracellular signaling pathways that comprise far more than those involved in neurite growth inhibition alone. Although ROCK function is currently studied in many different disease contexts, our review focuses on neurorestorative approaches in the CNS, especially in models of neurotrauma. Promising strategies to target ROCK by pharmacological small molecule inhibitors and RNAi approaches are evaluated for their outcome on regenerative growth and cellular protection both in preclinical and in clinical studies.

Keywords: Rho kinase, ROCK, neuroprotection, neurorestoration, cell survival, axon outgrowth

\section{INTRODUCTION}

Numerous factors are responsible for the failure of neurons to regenerate in the adult mammalian CNS and to restore functionality in traumatic and degenerative diseases of the nervous system. Axonal degeneration and neuronal death clearly limit the regenerative substrate. But even when the structural components are only partially lesioned, such as in the case of spinal cord injury, where neuron cell death is negligible, the extracellular environment and the nearly inexistent regenerative capacity of adult neurons counteract a successful functional restoration (Harel and Strittmatter, 2006; Yiu and He, 2006; Liu et al., 2011). Inhibitory signaling of myelin components and other repulsive guidance cues converges upon Rho-associated kinase (ROCK), which propagates this signal down to the cytoskeleton, influencing neurite growth and regeneration. This review will focus on ROCK as a promising molecular target for neurorestorative strategies in the CNS and highlight recent insights into ROCK-mediated effects on survival and regeneration.

\section{RHO KINASE (ROCK)}

The ROCK proteins are serine/threonine kinases with a large homology to other AGC kinases, such as myotonic dystrophy protein kinase (DMPK), DMPK-related CDC42-binding kinase (MRCK), and citron kinase (Pearce et al., 2010). Structurally ROCKs have a catalytic kinase domain at the $\mathrm{N}$-terminus, which is followed by a coiled-coil region, including the Rho-binding site, and a regulatory pleckstrin homology domain at the C-terminus with cysteine-rich repeats. The pleckstrin homology domain is likely to be involved in the stabilization of membrane association of ROCK. The C-terminus acts in an autoinhibitory manner on the kinase activity by interaction with the $\mathrm{N}$-terminus (Riento and Ridley, 2003). This interaction is disrupted by binding of active
Rho and thus increases kinase activity (Amano et al., 1999). Two highly homologous isoforms are known: ROCK1, which is mostly expressed in heart, lung, and other non-neuronal tissue, and ROCK2, which is preferentially found in brain, spinal cord, and muscle and shows an increased expression with age (Hashimoto et al., 1999; Komagome et al., 2000; Duffy et al., 2009). In the bovine brain, ROCK2 is abundantly expressed in neuronal cells in the gray matter in comparison to the white matter. Here, intense immunoreactivity for ROCK2 has been demonstrated in cortical, hippocampal, and cerebellar Purkinje cell neurons (Hashimoto et al., 1999). Preliminary results of an examination of human brain autopsies suggest that ROCK2 protein expression is not exclusively confined to neuronal cells, which, however, express the protein to a much higher level than non-neuronal cells (own unpublished data). The sequence homology between ROCK1 and ROCK2 is $\sim 65 \%$, and even $92 \%$ in the kinase domain whereas the C-terminus shows a higher divergence (Nakagawa et al., 1996; Matsui et al., 1998). Despite their structural similarities, ROCK1 and ROCK2 may have distinct roles in tissues where both isoforms are expressed to a comparable extent. However, an experimental in-depth dissection of differential roles of ROCK1 and ROCK2 in the same cell type has only been performed in non-neuronal cell culture models so far (Yoneda et al., 2005). Taking advantage of gene knockout technologies it has been found that in murine development ROCK1 is not able to completely compensate for the loss of the ROCK2 isoform. As a consequence, mice deficient for the ROCK2 gene exhibit severe hypercoagulable states with increased thrombus formation, placental dysfunction, and intrauterine growth retardation which commonly leads to fetal or early postnatal death in the offspring (Thumkeo et al., 2003). In a different ROCK2 knockout model mice were normal in gross brain anatomy but were severely altered in synaptic spine morphology, 
basal synaptic transmission, and hippocampal LTP. This was found to be attributed to dysfunctions of the actin cytoskeleton and the actin-binding protein cofilin (Zhou et al., 2009). A study that compared haploinsufficient ROCK1 and ROCK2 mice focused on vascular biology and examined the extent of neointima formation in the carotid artery. Here, ROCK1 haploinsufficiency was associated with reduced neointima formation as well as with decreased vascular smooth muscle cell proliferation and decreased levels of proinflammatory adhesion molecule expression (Noma et al., 2008).

\section{UPSTREAM ACTIVATORS AND DOWNSTREAM TARGETS OF ROCK}

The extracellular environment of the CNS is highly repulsive toward regenerating axons, which is largely attributed to the presence of inhibitory molecules on oligodendrocytes, myelin, and scar tissue. Among these we find Nogo, myelin-associated glycoprotein (MAG), and oligodendrocyte myelin glycoprotein (OMgp) which are regularly present on the surface of oligodendrocytes (Wang et al., 2002). Nogo, MAG, and OMgp have been shown to confer their inhibitory activity via a trimeric receptor complex comprising Nogo receptor 1 (NgR1), LINGO-1, and $\mathrm{p} 75^{\mathrm{NTR}}$ or TROY (Mi et al., 2004) and also via the paired immunoglobulin-like receptor B (PirB) as recently reported (Atwal et al., 2008). After ligand binding the $\mathrm{p} 75^{\mathrm{NTR}}$ receptor component activates the small GTPase RhoA, which has been identified as a main binding partner of ROCK (Ishizaki et al., 1996). Additionally, G-protein-coupled receptor (GPCR) stimulation by lysophosphatidic acid (LPA) or sphingosine-1 phosphate (S1P) results in the transformation of GDP-bound RhoA GTPase into the GTP-bound form, which is the active one. After binding to the rho-binding domain, active RhoA increases the kinase activity of ROCK by release of its autoinhibition. After this activation ROCK translocates to peripheral membranes (Leung et al., 1995). Following lesion, repulsive guidance molecules, which direct axonal outgrowth during embryogenesis, can be upregulated and act as regeneration inhibitors. This has been shown for Sema5A (Goldberg et al., 2004) and several Ephrins/Eph receptors (summarized in Goldshmit et al., 2006). Although ephrins and semaphorins employ a different receptor, parts of their downstream signaling similarly converge on the Rho/ROCK cascade (via ephexin and Rac1, respectively; Liu and Strittmatter, 2001; Shamah et al., 2001).

In contrast to the reversible action of RhoA, caspases have been shown to irreversibly activate ROCK by truncation and generation of a constitutively active form. ROCK activity in this context was necessary and sufficient for the apoptotic process by formation of membrane blebs and re-localization of fragmented DNA (Coleman et al., 2001; Sebbagh et al., 2001). Similar to caspases, granzyme B is able to proteolytically cleave and activate ROCK (Sebbagh et al., 2005).

Numerous downstream target proteins have been identified, which are regulated by ROCK phosphorylation. Many of these are involved in regulation of cell shape and motility, but others participate in cell cycle and survival pathways. Myosin light chain (MLC) is a substrate of activated ROCK and its phosphorylation results in actomyosin contraction (Amano et al., 1996). In addition ROCK can inactivate MLC phosphatase (MLCP), indirectly regulating
MLC phosphorylation, which results in conformational changes of myosin required for contraction of actin filaments (Kimura et al., 1996). Being a serine/threonine kinase, ROCK can activate LIM kinase-1 (LIMK1), which then inactivates cofilin/actin depolymerizing factor (ADF) by phosphorylation (Yang et al., 1998). As a consequence, cofilin is no longer able to severe filamentous actin (f-actin) and to depolymerize actin from the pointed ends, which promotes actin polymerization, initiation of growth cone collapse, and reduced axonal outgrowth or growth arrest ( $\mathrm{Ng}$ and Luo, 2004). ROCK2 has also been shown to phosphorylate the so-called ERM proteins, ezrin, radixin, and moesin (Matsui et al., 1998). ERM proteins act as molecular bridges between the plasma membrane and the actin cytoskeleton and therefore play essential roles in axon growth and regeneration (Arpin et al., 2011). Phosphorylation by ROCK reduces the head-to-tail association of ERM proteins, which stabilizes their open and active conformation. Adducin is a protein that binds to f-actin promoting the association of spectrin and f-actin. ROCK-mediated phosphorylation of adducin enhances its $\mathrm{f}$-actin-binding potential and thus regulates membrane ruffling and cell motility (Fukata et al., 1999). Elongation factor-1 alpha (EF-1 $\alpha)$ is another substrate of ROCK that has been shown to be phosphorylated in vitro, which results in decreased f-actin-binding activity of EF-1alpha (Izawa et al., 2000). Further targets of ROCK phosphorylation are collapsin response mediator protein 2 (CRMP2), vimentin, glial fibrillary acidic protein (GFAP), neurofilament, tau, and MAP2 (Kosako et al., 1997; Goto et al., 1998; Hashimoto et al., 1998; Arimura et al., 2000; Amano et al., 2003).

One of the most interesting and recently described downstream targets of ROCK is the phosphatase and tensin homolog (PTEN), which is directly activated by phosphorylation through ROCK in HEK cells and leukocytes (Li et al., 2005). The PTEN gene product is a phosphatase that acts as a tumor suppressor and is involved in cell cycle regulation. PTEN negatively regulates Akt/PKB signaling by antagonizing activated phosphatidylinositol $(3,4,5)$ trisphosphate $\left(\mathrm{PIP}_{3}\right)$, which is a canonical pathway employed by growth factors to regulate neuronal survival. Suppressing PTEN thus fosters $\mathrm{PIP}_{3}$ signaling via phosphatidylinositol-dependent kinase $1 / 2(\mathrm{PDK} 1 / 2)$ to activate Akt/PKB, which in turn activates Ras homolog enriched in brain (Rheb) through inhibition of the tuberous sclerosis complex 1/2 (Tsc1/2). Activated Rheb stimulates mTOR complex 1 (mTORC1) that finally leads to an enhancement of general translation with an increase in protein synthesis and cell growth (Guertin and Sabatini, 2007; Park et al., 2010). However, there is also a much closer link of ROCK to mTOR that has been elucidated in fibroblasts. Here, ROCK1 has been identified as mediator of the cell anchorage signal to the extracellular matrix by physically interacting with Tsc2. This in turn relays the signal to Rheb and finally mTOR (Park et al., 2011). A summary of the most important signaling pathways involving ROCK is presented in Figure 1.

\section{INHIBITION OF ROCK \\ SMALL MOLECULE INHIBITORS OF ROCK}

A plethora of different pharmacological inhibitors of ROCK have been synthesized, which structurally belong to different chemical groups (Mueller et al., 2005). Among the best characterized 


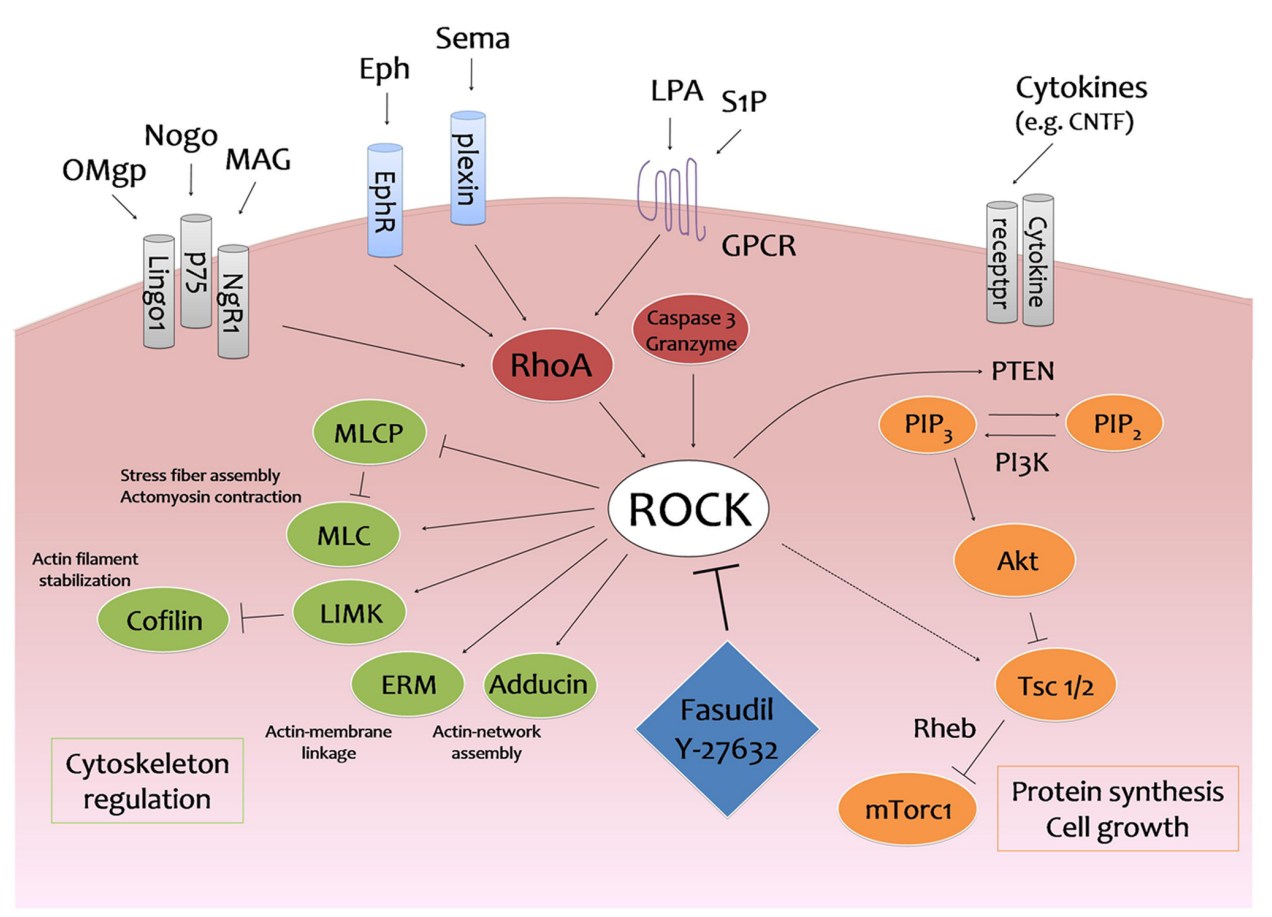

FIGURE 1 |The ROCK signaling pathway with focus on survival and regeneration. Nogo, MAG, OMgp present on the surface of oligodendrocytes confer their inhibitory activity via a trimeric receptor complex comprising NgR1, LINGO-1, and p75NTR to activate RhoA. Sema5A and several Ephrins can also contribute to RhoA activation via their plexin or Eph receptors, respectively. Additionally, G protein-coupled receptor (GPCR) stimulation by lysophosphatidic acid (LPA) or sphingosine-1 phosphate (S1P) results in the activation of the small GTPase RhoA. GTP-bound RhoA further activates ROCK to phosphorylate several substrates that are involved in regulation of cell shape and motility but also in survival pathways. Caspase-3 and granzyme B are able to proteolytically cleave and thus activate ROCK. Myosin light chain (MLC) is a substrate of activated ROCK and its phosphorylation results in actomyosin contraction. In addition ROCK can inactivate MLC phosphatase (MLCP) and thus indirectly regulate $M L C$ phosphorylation. Being a serine/threonine kinase, ROCK can activate LIM kinase-1 (LIMK1) that then inactivates cofilin/actin depolymerizing factor (ADF) by phosphorylation promoting actin filament stabilization. The phosphorylation of ERM proteins leads to Actin-membrane linkage. Adducin is a protein that after activation binds to f-actin promoting the association of spectrin and f-actin and thus assembling the actin network. Another downstream target of ROCK is PTEN, which negatively regulates Akt/PKB signaling by antagonizing PIP3. If active, Akt in turn activates Rheb because of inhibition of Tsc1/2, and subsequently stimulates mTORC1, which finally leads to an enhancement of general translation with an increase in protein synthesis and cell. ROCK1 may also physically interact with Tsc2. and most frequently used substances is Fasudil, a member of the isoquinoline series. Its main metabolite is Hydroxyfasudil, which shows a good bioavailability in various animal models in vivo even after oral administration (Hattori et al., 2004; Wang et al., 2005b). Y-27632 is a more specific ROCK inhibitor frequently used in biological and pharmacological experiments and a member of the 4-aminopyridine series. Over the years, these substances have been developed further based on indazole-, amide-, or urea backbones (Mueller et al., 2005; Liao et al., 2007). In order to optimize kinase selectivity, cell activity, microsomal stability, and pharmacogenetic properties, new pharmacological variants of the early ROCK inhibitors or even new pharmacological classes have been generated. Among them are chroman-3-amides (Chen et al., 2008), azaindol-based inhibitors (Schirok et al., 2008), and tetrahydroisoquinoline derivatives (Fang et al., 2010).

\section{DOMINANT-NEGATIVE MUTANTS AND RNAi-BASED APPROACHES}

Next to pharmacological inhibitors of ROCK, the expression of a dominant-negative mutant protein has been shown to act as a functional ROCK inhibitor both in vitro and in vivo in a spinal cord lesion model (Wu et al., 2009). Approaches using the RNAi technology to down regulate ROCK expression have been effectively applied in vitro and allow for an isoform- and cell type-specific view on the roles of ROCK1 and ROCK2 (Lock and Hotchin, 2009). Studies in fibroblasts and vascular smooth muscle cells have shown that both ROCK1 and ROCK2 seem to have distinct non-redundant functions. One example is the disassembly of stress fibers that is observed after knock-down of ROCK1 but not of ROCK2 in fibroblasts. In contrast, this seems to be mediated mainly by ROCK2 in smooth muscle cells (Yoneda et al., 2005; Wang et al., 2009). Furthermore, ROCK1 is cleaved and thereby constitutively activated by caspase- 3 at a conserved sequence at its C-terminus that is not found in ROCK2 (Sebbagh et al., 2001).

If a cell specific regulation of ROCK isoform expression in animal models in vivo is required, viral vector mediated transfer methods of shRNA expressing plasmids leading to RNAi-mediated knock-down of the target gene are a valuable option. Important considerations for viral vector design include size of the transgene, route of delivery, tropism, duration and regulation of gene expression, and side effects (for a review see Davidson and Breakefield, 
2003). Studying the role of ROCK2 in cell survival paradigms after optic nerve (ON) lesion, we were able to almost selectively infect retinal ganglion cells by AAV vectors. This enabled us to cell specifically regulate ROCK2 expression. Whereas the vector delivery via intravitreal injection was easy to handle, vector dosage in vivo was much more difficult and required an elaborate dose finding study (unpublished personal observation).

\section{TARGETING THE ROCK PATHWAY BY MODULATION OF UPSTREAM ACTIVATORS AND DOWNSTREAM TARGETS}

As described in the previous section, a plethora of upstream activators and downstream effectors of ROCK are known. Therefore, ROCK can also be regulated in an indirect manner. However, under these circumstances, significant off-target effects have to be considered. An obvious possibility to disrupt ROCK inhibitory signaling is provided by the use of the exoenzyme C3 transferase, which is an ADP ribosyl transferase that selectively ribosylates RhoA, RhoB, and RhoC proteins on asparagine residue 41 , rendering them inactive. It is available as a cell permeable recombinant protein and has been successfully applied in regeneration models of the $\mathrm{ON}$ and the spinal cord (Dergham et al., 2002; Bertrand et al., 2005; LordFontaine et al., 2008). Recently, this compound has been studied in a human clinical trial of patients with acute spinal cord injury, where its local application to the injury site in the first 7 days after injury led to an improvement in the ASIA motor score after 1 year in patients with cervical spinal cord lesions. If the patients encountered a thoracic spinal cord lesion the same treatment was not effective most probably because this patient group very often suffered from accompanying severe trauma to surrounding tissues creating an environment that allows for more systemic absorption of the locally applied C3 transferase (Fehlings et al., 2011). Looking even more upstream in the inhibitory cascade therapeutic approaches blocking Nogo function are most advanced. The Nogo-A extracellular peptide residues 1-40 (NEP1-40) can be used to antagonize Nogo receptor signaling. Alternatively, Nogo receptor fragments that bind Nogo-A or antibodies that block the Nogo receptor are available (for an overview see Schwab, 2010). A monoclonal antibody directed against Nogo-A is currently under clinical investigation in spinal cord injury patients (NCT00406016).

Closely related downstream targets of ROCK are LIM kinase (LIMK) and cofilin. Apart from RNA interference approaches, which can be applied to knock-down a target on the mRNA level, pharmacological inhibitors of LIMK have recently been generated (Ross-Macdonald et al., 2008; Harrison et al., 2009). They can effectively activate cofilin by lowering its phosphorylation and thereby enable it to severe filamentous actin again (Scott et al., 2010). However, their characterization is still incomplete and an application in neuronal tissue has not been demonstrated so far.

\section{EFFECTS OF ROCK INHIBITION NEURITE GROWTH AND REGENERATION}

Because ROCK is involved in the regulation of the cytoskeleton through downstream regulation of actin, myosin, and associated proteins, its effects on cellular functions such as motility and changes of cellular shape have been intensively studied.

Rho-associated kinase inhibition was shown to enhance neurite outgrowth in PC-12 or Ntera-2 cells in vitro (Zhang et al.,
2006; Lingor et al., 2007). The situation is more complex in primary neuronal cells, where the effect of ROCK inhibitor treatment seems to depend on the age of the cultures: neurite outgrowth was promoted best if the cultures were of embryonic or early postnatal age (Lehmann et al., 1999; Borisoff et al., 2003; Monnier et al., 2003). In contrast, adult retinal ganglion cells (RGC) grown on CNS myelin required the addition of a growth promoting factor, such as CNTF, or elevation of cAMP to promote neurite outgrowth through ROCK inhibition (Ahmed et al., 2009). This supports the hypothesis that the low intrinsic growth capacity of adult neurons is an important limiting factor for neurite regeneration, which cannot be overcome through regulation of the inhibitory cascade alone. Although there seems to be an intrinsic cellular ROCK activity that is present even if cells are cultured on arowth permissive substrate (Lingor et al., 2008), ROCK activity is considerably increased and outgrowth is inhibited when upstream activators of the ROCK signaling pathway such as CNS myelin components (e.g., Nogo-66, MAG, OMgp) are present (Alabed et al., 2006).

Along with their strong outgrowth promoting potential for RGC in vitro, intravitreally applied Y-27632 and Dimethylfasudil were shown to facilitate axon regeneration after $\mathrm{ON}$ crush in vivo (Lingor et al., 2007, 2008). However, the therapeutic window in both models was narrow and an attenuation of beneficial effects occurred at higher concentrations. Although the lower $K_{\mathrm{i}}$ value for p160ROCK of more potent ROCK inhibitors like Dimethylfasudil is preferred from a pharmacological point of view, the probability to observe off-target effects on other kinases seems to be higher, too (Davies et al., 2000). Consequently, treatment with very high concentrations of Fasudil or high concentrations of Dimethylfasudil resulted even in shorter neurite lengths in vitro. In vivo, application of an intermediate concentration of Dimethylfasudil was most effective for axonal regeneration (Lingor et al., 2007).

If a peripheral nerve graft is transplanted onto the stump of the CNS ON, a PNS environment can be created, which is semipermissive for regeneration. While a peripheral nerve does not express Nogo-A, it still shows expression of other inhibitory molecules that can activate the ROCK signaling cascade (e.g., MAG, Sema-III; Pasterkamp et al., 1998; Gupta et al., 2006). However, in this regeneration paradigm treatment with Y-27632 failed to significantly promote regeneration of $\mathrm{ON}$ axons. Although a combination treatment with CNTF resulted in an improved regenerative effect, the overall outcome was limited (Lingor et al., 2008). This may be due to an already robust basal regenerative response in the peripheral environment. In a sciatic nerve crush lesion model RhoA and its downstream target ROCK are activated in corresponding motoneurons. Interestingly, here the systemic application of Fasudil increased the regeneration of large diameter axons that led to a significantly faster increase of amplitudes of distally evoked compound muscle action potentials (Hiraga et al., 2006). The expression of RhoA in adult dorsal root ganglia sensory neurons rises dramatically after lesion. But it is even more important, that activated GTP-bound RhoA, which is undetectable in intact ganglia, is strongly upregulated in both DRG neurons and axons after injury. Consequently, application of Fasudil promoted axonal regeneration of transected DRG axons into the distal stump exvivo (Cheng et al., 2008). 
Crystallins have been shown to promote regeneration of retinal ganglion cells in vivo and are likely to represent one of the mediators of lens injury-induced regenerative response in the lesioned ON (Fischer et al., 2008). Interestingly, application of $\alpha$-crystallin to the vitreous resulted in a decreased RhoA and ROCK activity, and a reduction of $\mathrm{p}$-cofilin and $\mathrm{p}$-MLC, which was associated with increased axonal regeneration in vivo. Thus, pro-regenerative effects of crystallins may, at least partially, be attributed to the regulation of the RhoA/ROCK/cofilin pathway (Wang et al., 2011). Because $\alpha$-crystallin interacts with $\alpha 6$-integrin membrane receptor complexes and alters their cellular signaling (Menko and Andley, 2010) a speculative link to RhoA consists in the prevention of the GDP to GTP exchange of RhoA through integrin membrane complex binding of guanine nucleotide exchange factors (Wettschureck and Offermanns, 2002).

In the spinal cord lesion model a mutant Rho-binding/ pleckstrin homology protein was expressed in the rubrospinal tract using a lentiviral vector that leads to an abolishment of the Rho-binding activity of ROCK and thus functionally serves as a dominant-negative mutant of ROCK. This resulted in a better functional recovery of lesioned animals and in an increased axonal sprouting of rubrospinal tract axons (Wu et al., 2009). Comparing treatment effects of Fasudil, Y-27632, and C3 exoenzyme (a RhoA inhibitor), Fasudil was most efficient in improving the locomotor BBB score after moderate spinal cord injury at the T9/T10 region (Sung et al., 2003). However, if Fasudil was not applied directly after spinal cord lesion but only in a delayed treatment paradigm 4 weeks later it could not stimulate axonal sprouting or recover hind limb function anymore (Nishio et al., 2006). This was most probably due to the strong scarring activity after lesion that forms a rigid obstacle at 4 weeks after lesion and cannot be surpassed by axonal fibers even if they are disinhibited by Fasudil. As the transplantation of bone marrow stromal cells (BMSC) has been shown to promote functional recovery after spinal cord injury if transplanted into the lesion site, Fasudil was additionally applied in order to augment the BMSC effects on regeneration. Here, BMSC co-treatment with Fasudil significantly increased the number of sprouting spinal cord axons but was not able to improve the therapeutic effects of BMSC alone on locomotor function (Chiba et al., 2010). In a similar study on spinal cord injury assessing open field locomotor activity both Fasudil and BMSC treatment alone were not able to improve the outcome compared with sham treated control animals. However, the combination treatment showed a significantly enhanced locomotion at 8 and 9 weeks after lesion (Furuya et al., 2009).

Optimal ROCK inhibitor dosage is also important in spinal cord lesion models. Comparing two different dosages of intrathecally applied Y-27632 in a cervical 4/5 dorsal column transection model only the high dose of Y-27632 was able to stimulate sprouting of the dorsal ascending axons whereas low dose-treated animals did not benefit from treatment. The low dose-treated group even suffered from deficits in a functional footprint analysis in comparison to controls and showed less corticospinal tract axonal sprouting (Chan et al., 2005). One possible reason for this could be that the low dosage did not provide enough outgrowth disinhibition to overcome the inhibitory milieu or perhaps did not even reach the site of the growing axonal cones. Additionally, a relatively higher local concentration close to the scar could have elicited disproportionate undesirable effects of scar tissue including astroglia.

In view of all these data on neurite outgrowth and axonal regeneration it becomes obvious that the regenerative effect in vitro is usually more pronounced than in vivo. This can be due to the fact that frequently only one substrate is used to inhibit neurite regeneration of cultured neuronal cells in vitro. Even if preparations of whole CNS myelin are applied its integrity is disrupted and a tight physical contact is not maintained. The abundance of CNS myelin components, extracellular matrix scar tissue, and infiltration of inflammatory cells in combination with enhanced mechanical repression due to reactive edematous swelling and physical displacement of axonal tracts as seen in acute trauma models is only present in animal models in vivo (Sandvig et al., 2004; Yiu and He, 2006; Busch and Silver, 2007). As a consequence, many encouraging findings in vitro have not been successfully transferred to the in vivo setting. Therefore it is clear that ROCK inhibition by itself will not be sufficient to target all pathophysiological obstacles in regenerative approaches and thus will have to be complemented by combination treatments.

\section{CELL SURVIVAL}

The role of ROCK in cell death and survival has been addressed only recently as several ROCK substrates have been shown to be involved in the regulation of these processes (for review see Shi and Wei, 2007).

ROCK inhibition by Y-27632, HA-1077, HA-1004, and H-8 strongly promotes survival in Ntera-2 cells, a pluripotent human embryonic carcinoma cell line (Barbaric et al., 2011) and application of Dimethylfasudil leads to protection from apoptotic cell death in serum-deprived organotypic retinal cell cultures (Tura et al., 2009). Purkinje cell survival in organotypic cultures of mouse cerebella can be increased by both Dimethylfasudil and Y-27632 (Julien et al., 2008). In addition to improved cell survival of oxygen-glucose deprived PC-12 cells Fasudil application also triggered neurogenesis in the subventricular zone in a hypoxia/reoxygenation injury model (Yamashita et al., 2007; Ding et al., 2010b). We have evaluated the effects of ROCK inhibition on RGC. In a paradigm of primary RGC cell death in vitro, the application of Y-27632 is able to robustly increase survival and neurite outgrowth. These effects can be additively increased by the combination treatment with CNTF or, regarding cell survival, through co-treatment with the CDK5-inhibitor Indolinone A (Lingor et al., 2008; Bermel et al., 2009).

Other intracellular signaling cascades employed by ROCK in survival signaling have been described only recently. An important finding came from dissociated prostate stem cells, which undergo apoptosis upon dissociation lacking extracellular matrix contact. This has been shown to be associated with RhoA/ROCK activation, increased PTEN, and reduced Akt activities. Treatment with Y-27632 reduced PTEN activation and improved stem cell survival, even though PTEN activity alone was not sufficient to mediate cell death in this paradigm (Zhang et al., 2011). The distinguished role of PTEN for neuronal cell survival was underlined in studies where a conditional deletion of PTEN or Tscl was used to increase mTOR activity in RGC after ON lesion (Park et al., 2008). This resulted 
in a strong increase of surviving RGC and at the same time was associated with an enhanced regenerative response of ON axons.

Apart from the experimental evidence linking inhibition of ROCK and cell survival, there are complementary findings that demonstrate increased apoptosis upon ROCK activation. For example, increased phosphorylation of the ROCK effector MLC and actomyosin contraction in apoptotic cells regulate apoptotic membrane blebbing (Mills et al., 1998). ROCK may also promote apoptosis through increased ezrin phosphorylation that leads to activation and clustering of Fas, a component of the receptor-associated death-inducing signaling complex (Piazzolla et al., 2005). This signaling cascade can be inhibited by treatment with Y-27632 as shown in Jurkat cells (Hebert et al., 2008).

\section{SIMULTANEOUS MODULATION OF NEURITE OUTGROWTH AND CELL SURVIVAL - PROS AND CONS}

Whereas the blocking of ROCK as a central target in neurite outgrowth inhibitory signaling is a rather straightforward approach, a similarly powerful handle is more difficult to find in regard of cell survival regulation. As described before, cell survival responses after ROCK inhibition are most probably indirectly mediated and have been shown to involve MAPK and Akt signaling pathways (Lingor et al., 2008). However, there has been no study in neuronal cells so far which has identified such an intermediate signaling partner. The lack of knowledge concerning these intermediate signaling partners in cell protective signaling renders the precalculation of combinatorial treatments a difficult task. In the case of the co-application of Y-27632 and CNTF in the ON crush lesion paradigm, we noted a differential impact of CNTF and Y-27632 on mitogen-activated protein kinase (MAPK), Akt and signal transducer and activator of transcription 3 (STAT3). The MAPK pathway was activated in an additive manner by both compounds. To a lesser extent this held true also for the Akt-pathway as demonstrated by Akt phosphorylation. However, the application of Y-27632 markedly reduced the CNTF-evoked activation of STAT3. Thus, inhibition of ROCK in RGC attenuates some of the CNTF-mediated effects (via STAT3) while the MAPK- and Aktpathway are triggered in an additive manner. These data suggest that the opposing actions of CNTF and Y-27632 on the phosphorylation of STAT3 could be responsible for the lack of an additive effect on RGC survival in the corresponding ON axotomy model in vivo (Lingor et al., 2008). Also, axonal regeneration after ON crush was less pronounced than expected in this combinatorial treatment paradigm. Here, the attenuation of STAT3 activation caused by ROCK inhibition could be responsible because STAT3 signaling has been associated with axon regeneration in RGC (Kretz et al., 2005) and other neuronal cells in the CNS and PNS (Qiu et al., 2005; Bareyre et al., 2011). In view of these data on axonal regeneration and cell survival it is important to point out, that it would be highly preferable to modulate both parameters by targeting only one substrate. In the case of combination therapies, however, the selection of a suitable combination partner has to be done carefully.

\section{ROCK INHIBITION IN GLIAL AND INFLAMMATORY CELLS IN THE CNS}

After systemic application of pharmacological substances a cell specific targeting is less predictable. Thus, inhibition of ROCK will likely also modulate glial and inflammatory cell responses which in turn may affect the regenerative and cell survival response.

Concerning glial cells, it has been shown that Fasudil upregulates glutamate transport via EAAT1/2 subsequent to actin remodeling in murine cultured astrocytes (Lau et al., 2011a) and Dimethylfasudil reduced reactive astrocytic gliosis in the rodent retina after ON crush (Tura et al., 2009). Furthermore, a transcriptomic profiling of astrocytes treated with Fasudil did not only reveal an upregulation of genes involved in cellular shape and motility but also of genes involved in cell survival such as BDNF (Lau et al., 2011b). Enhanced neurogenesis in the subventricular zone upon treatment with Fasudil was attributed to an increased production of granulocyte colony-stimulating factor (G-CSF) from astrocytes (Ding et al., 2010b). Microglial inflammatory responses seem to be suppressed by ROCK inhibition as has been shown in various experimental paradigms. The injection of lysophosphatidylcholine (LPC), a major phospholipid component of the atherogenic oxidized LDL, is known to increase astrocyte and microglia accumulation in neuronal tissue and also elevates iNOS expression. If Fasudil is systemically applied, it is able to attenuate these LPC induced responses in the rat striatum and also protects from neuronal cell loss (Sheikh et al., 2009). In addition, Fasudil protection of hippocampal neurons against hypoxia-reoxygenation injury was shown to be mainly due to the suppression of microglial inflammatory responses (Ding et al., 2010a). However, if C3 transferase is used to inactivate Rho GTPases being upstream of ROCK, this causes a transformation of microglial cells rather toward an activated phenotype in culture and triggers the release of nitric oxide and various proinflammatory cyto- and chemokines - an effect that is not observed with the ROCK inhibitors Y-27632 or Fasudil (Hoffmann et al., 2008).

The role of ROCK inhibition has also been studied in classical animal models of inflammatory CNS disease. For example, both a parenteral and an oral administration of Fasudil prevented the development of experimental autoimmune encephalomyelitis (EAE) in mice. Together with a down-regulation of interleukin17 and a decrease in the interferon-gamma/interleukin- 4 ratio Fasudil significantly reduced the specific proliferation of lymphocytes. Overall, the infiltration of inflammatory cells was markedly decreased and acute axonal transections were attenuated as shown by immunohistochemical analysis (Sun et al., 2006). The Fasudilmediated attenuation of EAE development was confirmed in a more recent study using a different induction model of the disease. Here, the T-cell proliferation was markedly reduced in addition to a down-regulation of interleukin-17 (Yu et al., 2010). This could be due to a decreased phosphorylation of interferon regulatory factor 4 (IRF4) which is known to regulate the synthesis of IL17 and IL-21 and implicates ROCK in the development of other autoimmune diseases like rheumatoid arthritis and systemic lupus erythematosus (Biswas et al., 2010). Hints for a possible influence of ROCK on T-cell migration comes from a recent study in which microtubules were disrupted with nocodazole preventing the formation of lamellipodia. As a consequence the migratory behavior is reduced because cells can migrate only by membrane blebbing. It was found that the nocodazole-induced microtubule depolymerization was associated with a stimulation of RhoA activity and that the resulting defect in cell migration could be 
rescued by ROCK inhibition with Y-27632 leading to an increased microtubule stability (Takesono et al., 2010).

\section{THERAPEUTIC STRATEGIES USING ROCK INHIBITION}

From a therapeutic point of view, the experimental use of small molecule inhibitors of ROCK is well established. Many experimental studies in animals focus on their vasodilator effect in the vascular system which results from the inhibition of ROCK in vascular smooth cells. As one example, ROCK inhibition is able to increase cerebral blood flow via endothelial mechanisms and is protective in stroke (Rikitake et al., 2005; Shin et al., 2007). However, ROCK inhibition also ameliorates post myocardial infarct heart failure by suppressing left ventricular remodeling (Hattori et al., 2004), reduces cardiac hypertrophy in apolipoprotein E deficient mice (Wang et al., 2005a), improves monocrotaline-induced fatal pulmonary hypertension in rats (Abe et al., 2004), and is preventive for ischemia/reperfusion-induced acute renal failure (Teraishi et al., 2004). In regard to neuroprotection, Y-27632 has been applied to animal models of Huntington's disease and spinal muscular atrophy where it improved rotarod performance and prolonged survival, respectively (Li et al., 2009; Bowerman et al., 2010). Recently, ROCK inhibitors were also tested in preclinical models of neuropathic and nociceptive pain (Boyce-Rustay et al., 2010), spinal cord lesion (Furuya et al., 2009), sexual dysfunction (Li et al., 2011), and multiple sclerosis (Sun et al., 2006), all with encouraging results in regard of disease modulation.

Because of these strong preclinical data ROCK inhibition has already been tested in human studies almost exclusively using Fasudil. Taking advantage of the strong vasodilator effect it was possible to successfully suppress both coronary artery vasospasm and cerebral vasospasm that often appears after aneurysmal subarachnoid hemorrhage (SAH; Masumoto et al., 2002; Zhao et al., 2006). Furthermore, Fasudil significantly improved the patient's clinical outcome if applied in the first $48 \mathrm{~h}$ after acute ischemic stroke (Shibuya et al., 2005). Overall, Fasudil showed a safe clinical profile without the occurrence of serious adverse effects and has been approved for the treatment of cerebral vasospasm after SAH in Japan (Suzuki et al., 2008; Iwabuchi et al., 2011). Currently, a phase II clinical trial is ongoing that evaluates the effect of ROCK inhibition with Fasudil for the prevention of carotid stenosis (NCT00670202). Other clinical phase I/II trials investigate the treatment of glaucoma (NCT00846989) or spinal cord injury (NCT00500812). An already terminated phase I clinical study for glaucoma treatment with SNJ-1656 confirmed the Japanese safety data obtained for SAH, did not show any systemic adverse effects and reported only minor side effects in a 7-day repeated instillation trial (Tanihara et al., 2008). However, it has to be considered that

\section{REFERENCES}

Abe, K., Shimokawa, H., Morikawa, K., Uwatoku, T., Oi, K., Matsumoto, Y., Hattori, T., Nakashima, Y., Kaibuchi, K., Sueishi, K., and Takeshit, A. (2004). Long-term treatment with a Rho-kinase inhibitor improves monocrotaline-induced fatal pulmonary hypertension in rats. Circ. Res. 94, 385-393.
Ahmed, Z., Berry, M., and Logan, A. (2009). ROCK inhibition promotes adult retinal ganglion cell neurite outgrowth only in the presence of growth promoting factors. Mol. Cell. Neurosci. 42, 128-133.

Alabed, Y. Z., Grados-Munro, E., Ferraro, G. B., Hsieh, S. H., and Fournier, A. E. (2006). Neuronal responses to myelin are mediated

systemic adverse or off-target effects after ocular application are less likely to occur because the substance remains rather in a confined local compartment and does not reach comparable systemic concentrations.

The use of isoform specific targeting with siRNA as a therapeutic tool is still limited because of the difficult delivery and only moderate stability of the molecules in a therapeutic setting in vivo. Therefore, the development of small molecule inhibitors for isoform specific inhibition of ROCK is greatly awaited. As one example, SLx-2119 represents one of the first isoform specific pharmacological inhibitors of ROCK targeting selectively ROCK2 (Schueller et al., 2006).

\section{SUMMARY AND CONCLUSION}

Rho-associated kinase signaling is a major obstacle for successful regeneration in the CNS. Once this deleterious cascade is activated after acute traumatic lesion or in chronic neurodegenerative diseases the outcome of axonal outgrowth/regeneration and of cellular survival is limited. However, if pathological ROCK activation can be effectively prevented, neurological sequelae may be mitigated, too. Whereas the regeneration disinhibiting potential of ROCK inhibition is well known and has been experimentally characterized in detail, cell protective responses have emerged as a new focus. After first successful applications of ROCK inhibition in cell death paradigms in culture models in vitro it has later successfully been transferred to neurologic disease models such as ON lesion and spinal cord trauma but also to neurodegenerative diseases models like Huntington's disease and spinal muscular atrophy. Now, first hints on the underlying neuroprotective mechanisms emerge. Some of these seem to be linked to the modulation of the recently discovered ROCK targets involving PTEN/Akt or Tsc1/2 but may also be associated with modulatory effects on glial and inflammatory cells in the CNS. The development of new pharmacological inhibitors with enhanced specificity and less off-target effects, improved bioavailability and compound stability in addition to selective targeting of ROCK isoforms now enables us to better counteract deregulated ROCK. Due to the good clinical safety profile of Fasudil in humans, this compound is currently under investigation in various clinical trials that focus on the compromised cardiovascular system. However, based on the many promising findings in CNS disease models, it has potential to also enter this area of clinical research.

\section{ACKNOWLEDGMENTS}

Lars Tönges has received grant support from the Forschungsförderungsprogramm of the University Medicine Göttingen. Paul Lingor and Mathias Bähr were supported by the DFG Research Center for Molecular Physiology of the Brain (CMPB), Göttingen.

by rho kinase. J. Neurochem. 96, 1616-1625.

Amano, M., Chihara, K., Nakamura, N., Kaneko, T., Matsuura, Y., and Kaibuchi, K. (1999). The $\mathrm{COOH}$ terminus of Rho-kinase negatively regulates rho-kinase activity. J. Biol. Chem. 274, 32418-32424.

Amano, M., Ito, M., Kimura, K., Fukata, Y., Chihara, K., Nakano,
T., Matsuura, Y., and Kaibuchi, K. (1996). Phosphorylation and activation of myosin by Rho-associated kinase (Rho-kinase). J. Biol. Chem. 271, 20246-20249.

Amano, M., Kaneko, T., Maeda, A., Nakayama, M., Ito, M., Yamauchi, T., Goto, H., Fukata, Y., Oshiro, N., Shinohara, A., Iwamatsu, A., and Kaibuchi, K. (2003). Identification 
of Tau and MAP2 as novel substrates of Rho-kinase and myosin phosphatase. J. Neurochem. 87, 780-790.

Arimura, N., Inagaki, N., Chihara, K., Menager, C., Nakamura, N., Amano, M., Iwamatsu, A., Goshima, Y., and Kaibuchi, K. (2000). Phosphorylation of collapsin response mediator protein-2 by Rho-kinase. Evidence for two separate signaling pathways for growth cone collapse. J. Biol. Chem. 275, 23973-23980.

Arpin, M., Chirivino, D., Naba, A., and Zwaenepoel, I. (2011). Emerging role for ERM proteins in cell adhesion and migration. Cell Adh. Migr. 5, 199-206.

Atwal, J. K., Pinkston-Gosse, J., Syken, J., Stawicki, S., Wu, Y., Shatz, C., and Tessier-Lavigne, M. (2008). PirB is a functional receptor for myelin inhibitors of axonal regeneration. Science 322, 967-970.

Barbaric, I., Jones, M., Harley, D. J., Gokhale, P. J., and Andrews, P. W. (2011). High-content screening for chemical modulators of embryonal carcinoma cell differentiation and survival. J. Biomol. Screen. 16, 603-617.

Bareyre, F. M., Garzorz, N., Lang, C., Misgeld, T., Buning, H., and Kerschensteiner, M. (2011). In vivo imaging reveals a phase-specific role of STAT3 during central and peripheral nervous system axon regeneration. Proc. Natl. Acad. Sci. U.S.A. 108, 6282-6287.

Bermel, C., Tonges, L., Planchamp, V., Gillardon, F., Weishaupt, J. H., Dietz, G. P., Bahr, M., and Lingor, P. (2009). Combined inhibition of Cdk5 and ROCK additively increase cell survival, but not the regenerative response in regenerating retinal ganglion cells. Mol. Cell. Neurosci. 42, 427-437.

Bertrand, J., Winton, M. J., RodriguezHernandez, N., Campenot, R. B., and McKerracher, L. (2005). Application of Rho antagonist to neuronal cell bodies promotes neurite growth in compartmented cultures and regeneration of retinal ganglion cell axons in the optic nerve of adult rats. $J$. Neurosci. 25, 1113-1121.

Biswas, P. S., Gupta, S., Chang, E., Song, L., Stirzaker, R. A., Liao, J. K., Bhagat, G., and Pernis, A. B. (2010). Phosphorylation of IRF4 by ROCK2 regulates IL-17 and IL-21 production and the development of autoimmunity in mice. J. Clin. Invest. 120, 3280-3295.

Borisoff, J. F., Chan, C. C., Hiebert, G. W., Oschipok, L., Robertson, G. S., Zamboni, R., Steeves, J. D., and Tetzlaff, W. (2003). Suppression of Rho-kinase activity promotes axonal growth on inhibitory CNS substrates. Mol. Cell. Neurosci. 22, 405-416.

Bowerman, M., Beauvais, A., Anderson, C. L., and Kothary, R. (2010). Rho-kinase inactivation prolongs survival of an intermediate SMA mouse model. Hum. Mol. Genet. 19, 1468-1478.

Boyce-Rustay, J. M., Simler, G. H., McGaraughty, S., Chu, K. L., Wensink, E. J., Vasudevan, A., and Honore, P. (2010). Characterization of Fasudil in preclinical models of pain. J. Pain 11, 941-949.

Busch, S. A., and Silver, J. (2007). The role of extracellular matrix in CNS regeneration. Curr. Opin. Neurobiol. 17, 120-127.

Chan, C. C., Khodarahmi, K., Liu, J., Sutherland, D., Oschipok, L. W., Steeves, J. D., and Tetzlaff, W. (2005). Dose-dependent beneficial and detrimental effects of ROCK inhibitor Y27632 on axonal sprouting and functional recovery after rat spinal cord injury. Exp. Neurol. 196, 352-364.

Chen, Y. T., Bannister, T. D., Weiser, A., Griffin, E., Lin, L., Ruiz, C., Cameron, M. D., Schurer, S., Duckett, D., Schroter, T., LoGrasso, P., and Feng, Y. (2008). Chroman3-amides as potent Rho kinase inhibitors. Bioorg. Med. Chem. Lett. 18, 6406-6409.

Cheng, C., Webber, C. A., Wang, J., Xu, Y., Martinez, J. A., Liu, W. Q., McDonald, D., Guo, G. F., Nguyen, M. D., and Zochodne, D. W. (2008). Activated RHOA and peripheral axon regeneration. Exp. Neurol. 212, 358-369.

Chiba, Y., Kuroda, S., Shichinohe, H., Hokari, M., Osanai, T., Maruichi, K., Yano, S., Hida, K., and Iwasaki, Y. (2010). Synergistic effects of bone marrow stromal cells and a Rho kinase (ROCK) inhibitor, fasudil on axon regeneration in rat spinal cord injury. Neuropathology 30, 241-250.

Coleman, M. L., Sahai, E. A., Yeo, M., Bosch, M., Dewar, A., and Olson, M. F. (2001). Membrane blebbing during apoptosis results from caspasemediated activation of ROCK I. Nat. Cell Biol. 3, 339-345.

Davidson, B. L., and Breakefield, X. O. (2003). Viral vectors for gene delivery to the nervous system. Nat. Rev. Neurosci. 4, 353-364.

Davies, S. P., Reddy, H., Caivano, M., and Cohen, P. (2000). Specificity and mechanism of action of some commonly used protein kinase inhibitors. Biochem. J. 351, 95-105.

Dergham, P., Ellezam, B., Essagian, C., Avedissian, H., Lubell, W. D., and
McKerracher, L. (2002). Rho signaling pathway targeted to promote spinal cord repair. J. Neurosci. 22, 6570-6577.

Ding, J., Li, Q. Y., Wang, X., Sun, C. H., Lu, C. Z., and Xiao, B. G. (2010a). Fasudil protects hippocampal neurons against hypoxiareoxygenation injury by suppressing microglial inflammatory responses in mice. J. Neurochem. 114, 1619-1629.

Ding, J., Li, Q. Y., Yu, J. Z., Wang, X., Sun, C. H., Lu, C. Z., and Xiao, B. G. (2010b). Fasudil, a Rho kinase inhibitor, drives mobilization of adult neural stem cells after hypoxia/reoxygenation injury in mice. Mol. Cell. Neurosci. 43, 201-208.

Duffy, P., Schmandke, A., Sigworth, J., Narumiya, S., Cafferty, W. B., and Strittmatter, S. M. (2009). Rhoassociated kinase II (ROCKII) limits axonal growth after trauma within the adult mouse spinal cord. J. Neurosci. 29, 15266-15276.

Fang, X., Yin, Y., Chen, Y. T., Yao, L., Wang, B., Cameron, M. D., Lin, L., Khan, S., Ruiz, C., Schroter, T., Grant, W., Weiser, A., Pocas, J., Pachori, A. Schurer, S., Lograsso, P., and Feng, Y. (2010). Tetrahydroisoquinoline derivatives as highly selective and potent Rho kinase inhibitors. J. Med. Chem. 53, 5727-5737.

Fehlings, M. G., Theodore, N., Harrop, J., Maurais, G., Kuntz, C., Shaffrey, C. I., Kwon, B. K., Chapman, J., Yee, A., Tighe, A., and McKerracher, L. (2011). A phase I/IIa clinical trial of a recombinant Rho protein antagonist in acute spinal cord injury. $J$. Neurotrauma 28, 787-796.

Fischer, D., Hauk, T. G., Muller, A., and Thanos, S. (2008). Crystallins of the beta/gamma-superfamily mimic the effects of lens injury and promote axon regeneration. Mol. Cell. Neurosci. 37, 471-479.

Fukata, Y., Oshiro, N., Kinoshita, N. Kawano, Y., Matsuoka, Y., Bennett, V., Matsuura, Y., and Kaibuchi, K. (1999). Phosphorylation of adducin by Rho-kinase plays a crucial role in cell motility. J. Cell Biol. 145, 347-361.

Furuya, T., Hashimoto, M., Koda, M., Okawa, A., Murata, A., Takahashi, K., Yamashita, T., and Yamazaki, M. (2009). Treatment of rat spinal cord injury with a Rho-kinase inhibitor and bone marrow stromal cell transplantation. Brain Res. 1295, 192-202.

Goldberg, J. L., Vargas, M. E., Wang, J. T., Mandemakers, W., Oster, S. F., Sretavan, D. W., and Barres, B. A. (2004). An oligodendrocyte lineage-specific semaphorin, Sema5A, inhibits axon growth by retinal ganglion cells. $J$. Neurosci. 24, 4989-4999.

Goldshmit, Y., McLenachan, S., and Turnley, A. (2006). Roles of Eph receptors and ephrins in the normal and damaged adult CNS. Brain Res. Rev. 52, 327-345.

Goto, H., Kosako, H., Tanabe, K., Yanagida, M., Sakurai, M., Amano, M., Kaibuchi, K., and Inagaki, M. (1998). Phosphorylation of vimentin by Rho-associated kinase at a unique amino-terminal site that is specifically phosphorylated during cytokinesis. J. Biol. Chem. 273, 11728-11736.

Guertin, D. A., and Sabatini, D. M. (2007). Defining the role of mTOR in cancer. Cancer Cell 12, 9-22.

Gupta, R., Rummler, L. S., Palispis, W., Truong, L., Chao, T., Rowshan, K., Mozaffar, T., and Steward, O. (2006). Local down-regulation of myelin-associated glycoprotein permits axonal sprouting with chronic nerve compression injury. Exp. Neurol. 200, 418-429.

Harel, N. Y., and Strittmatter, S. M. (2006). Can regenerating axons recapitulate developmental guidance during recovery from spinal cord injury? Nat. Rev. Neurosci. 7, 603-616.

Harrison, B. A., Whitlock, N. A., Voronkov, M. V., Almstead, Z. Y., Gu, K. J., Mabon, R., Gardyan, M., Hamman, B. D., Allen, J., Gopinathan, S., McKnight, B., Crist, M., Zhang, Y., Liu, Y., Courtney, L. F., Key, B., Zhou, J., Patel, N., Yates, P. W., Liu, Q., Wilson, A. G., Kimball, S. D., Crosson, C. E., Rice, D. S., and Rawlins, D. B. (2009). Novel class of LIMkinase 2 inhibitors for the treatment of ocular hypertension and associated glaucoma. J. Med. Chem. 52, 6515-6518.

Hashimoto, R., Nakamura, Y., Goto, H., Wada, Y., Sakoda, S., Kaibuchi, K., Inagaki, M., and Takeda, M. (1998). Domain- and site-specific phosphorylation of bovine NF-L by Rho-associated kinase. Biochem. Biophys. Res. Commun. 245, 407-411.

Hashimoto, R., Nakamura, Y., Kosako, H., Amano, M., Kaibuchi, K., Inagaki, M., and Takeda, M. (1999). Distribution of Rho-kinase in the bovine brain. Biochem. Biophys. Res. Commun. 263, 575-579.

Hattori, T., Shimokawa, H., Higashi, M., Hiroki, J., Mukai, Y., Tsutsui, H., Kaibuchi, K., and Takeshita, A. (2004). Long-term inhibition of Rho-kinase suppresses left ventricular remodeling after myocardial infarction in mice. Circulation 109, 2234-2239. 
Hebert, M., Potin, S., Sebbagh, M., Bertoglio, J., Breard, J., and Hamelin, J. (2008). Rho-ROCK-dependent ezrin-radixin-moesin phosphorylation regulates Fas-mediated apoptosis in Jurkat cells. J. Immunol. 181, 5963-5973.

Hiraga, A., Kuwabara, S., Doya, H., Kanai, K., Fujitani, M., Taniguchi, J., Arai, K., Mori, M., Hattori, T., and Yamashita, T. (2006). Rho-kinase inhibition enhances axonal regeneration after peripheral nerve injury. $J$. Peripher. Nerv. Syst. 11, 217-224.

Hoffmann, A., Hofmann, F., Just, I., Lehnardt, S., Hanisch, U. K., Bruck, W., Kettenmann, H., Ahnert-Hilger, G., and Holtje, M. (2008). Inhibition of Rho-dependent pathways by Clostridium botulinum C3 protein induces a proinflammatory profile in microglia. Glia 56, 1162-1175.

Ishizaki, T., Maekawa, M., Fujisawa, K., Okawa, K., Iwamatsu, A., Fujita, A., Watanabe, N., Saito, Y., Kakizuka, A., Morii, N., and Narumiya, S. (1996). The small GTP-binding protein Rho binds to and activates a 160 $\mathrm{kDa}$ Ser/Thr protein kinase homologous to myotonic dystrophy kinase. EMBO J. 15, 1885-1893.

Iwabuchi, S., Yokouchi, T., Hayashi, M., Sato, K., Saito, N., Hirata, Y., Harashina, J., Nakayama, H., Akahata, M., Ito, K., Kimura, H., and Aoki, K. (2011). Intraarterial Administration of Fasudil Hydrochloride for Vasospasm Following Subarachnoid Haemorrhage: experience of 90 Cases. Acta Neurochir. Suppl. 110, 179-181.

Izawa, T., Fukata, Y., Kimura, T., Iwamatsu, A., Dohi, K., and Kaibuchi, K. (2000). Elongation factor-1 alpha is a novel substrate of rho-associated kinase. Biochem. Biophys. Res. Commun. 278, 72-78.

Julien, S., Schnichels, S., Teng, H., Tassew, N., Henke-Fahle, S., Mueller, B. K., and Monnier, P. P. (2008). Purkinje cell survival in organotypic cultures: implication of Rho and its downstream effector ROCK. $J$. Neurosci. Res. 86, 531-536.

Kimura, K., Ito, M., Amano, M., Chihara, K., Fukata, Y., Nakafuku, M., Yamamori, B., Feng, J., Nakano, T., Okawa, K., Iwamatsu, A., and Kaibuchi, K. (1996). Regulation of myosin phosphatase by Rho and Rho-associated kinase (Rhokinase). Science 273, 245-248.

Komagome, R., Kimura, K., and Saito, M. (2000). Postnatal changes in Rho and Rho-related proteins in the mouse brain. Jpn. J. Vet. Res. 47, 127-133.

Kosako, H., Amano, M., Yanagida, M., Tanabe, K., Nishi, Y., Kaibuchi, K., and Inagaki, M. (1997). Phosphorylation of glial fibrillary acidic protein at the same sites by cleavage furrow kinase and Rho-associated kinase. J. Biol. Chem. 272, 10333-10336.

Kretz, A., Happold, C. J., Marticke, J. K., and Isenmann, S. (2005). Erythropoietin promotes regeneration of adult CNS neurons via Jak2/Stat3 and PI3K/AKT pathway activation. Mol. Cell. Neurosci. 29, 569-579.

Lau, C. L., O'Shea, R. D., Broberg, B. V., Bischof, L., and Beart, P. M. (2011a). The Rho kinase inhibitor Fasudil upregulates astrocytic glutamate transport subsequent to actin remodelling in murine cultured astrocytes. Br. J. Pharmacol. 163, 533-545.

Lau, C. L., Perreau, V. M., Chen, M. J., Cate, H. S., Merlo, D., Cheung, N. S., O'Shea, R. D., and Beart, P. M. (2011b). Transcriptomic profiling of astrocytes treated with the Rho kinase inhibitor fasudil reveals cytoskeletal and pro-survival responses. J. Cell. Physiol. doi: 10.1002/jcp.22838. [Epub ahead of print].

Lehmann, M., Fournier, A., SellesNavarro, I., Dergham, P., Sebok, A., Leclerc, N., Tigyi, G., and McKerracher, L. (1999). Inactivation of Rho signaling pathway promotes CNS axon regeneration. J. Neurosci. 19, 7537-7547.

Leung, T., Manser, E., Tan, L., and Lim, L. (1995). A novel serine/threonine kinase binding the Ras-related RhoA GTPase which translocates the kinase to peripheral membranes. J. Biol. Chem. 270, 29051-29054.

Li, M., Huang, Y., Ma, A. A., Lin, E., and Diamond, M. I. (2009). Y-27632 improves rotarod performance and reduces huntingtin levels in $\mathrm{R} 6 / 2$ mice. Neurobiol. Dis. 36, 413-420.

Li, W. J., Park, K., Paick, J. S., and Kim, S. W. (2011). Chronic treatment with an oral rho-kinase inhibitor restores erectile function by suppressing corporal apoptosis in diabetic rats. $J$. Sex. Med. 8, 400-410.

Li, Z., Dong, X., Wang, Z., Liu, W., Deng, N., Ding, Y., Tang, L., Hla, T., Zeng, R., Li, L., and Wu, D. (2005). Regulation of PTEN by Rho small GTPases. Nat. Cell Biol. 7, 399-404.

Liao, J. K., Seto, M., and Noma, K. (2007). Rho kinase (ROCK) inhibitors. J. Cardiovasc. Pharmacol. 50, 17-24.

Lingor, P., Teusch, N., Schwarz, K., Mueller, R., Mack, H., Bahr, M., and Mueller, B. K. (2007). Inhibition of Rho kinase (ROCK) increases neurite outgrowth on chondroitin sulphate proteoglycan in vitro and axonal regeneration in the adult optic nerve in vivo. J. Neurochem. 103, 181-189.

Lingor, P., Tonges, L., Pieper, N., Bermel, C., Barski, E., Planchamp, V., and Bahr, M. (2008). ROCK inhibition and CNTF interact on intrinsic signalling pathways and differentially regulate survival and regeneration in retinal ganglion cells. Brain 131, 250-263.

Liu, B. P., and Strittmatter, S. M. (2001). Semaphorin-mediated axonal guidance via Rho-related G proteins. Curr. Opin. Cell Biol. 13, 619-626.

Liu, K., Tedeschi, A., Park, K. K., and He, Z. (2011). Neuronal intrinsic mechanisms of axon regeneration. Annu. Rev. Neurosci. 34, 131-152.

Lock, F. E., and Hotchin, N. A (2009). Distinct roles for ROCK1 and ROCK2 in the regulation of keratinocyte differentiation. PLoS ONE 4, e8190. doi:10.1371/journal.pone. 0008190

Lord-Fontaine, S., Yang, F., Diep, Q. Dergham, P., Munzer, S., Tremblay, P., and McKerracher, L. (2008). Local inhibition of Rho signaling by cell-permeable recombinant protein BA-210 prevents secondary damage and promotes functional recovery following acute spinal cord injury. J. Neurotrauma 25, 1309-1322.

Masumoto, A., Mohri, M., Shimokawa, H., Urakami, L., Usui, M., and Takeshita, A. (2002). Suppression of coronary artery spasm by the Rhokinase inhibitor fasudil in patients with vasospastic angina. Circulation 105, 1545-1547.

Matsui, T., Maeda, M., Doi, Y., Yonemura, S., Amano, M., Kaibuchi, K. and Tsukita, S. (1998). Rho-kinase phosphorylates COOH-terminal threonines of ezrin/radixin/moesin (ERM) proteins and regulates their head-to-tail association. J. Cell Biol. 140, 647-657.

Menko, A. S., and Andley, U. P. (2010). alphaA-Crystallin associates with alpha6 integrin receptor complexes and regulates cellular signaling. Exp. Eye Res. 91, 640-651.

Mi, S., Lee, X., Shao, Z., Thill, G., Ji, B., Relton, J., Levesque, M., Allaire, N., Perrin, S., Sands, B., Crowell, T., Cate, R. L., McCoy, J. M., and Pepinsky, R. B. (2004). LINGO-1 is a component of the Nogo- 66 receptor/p75 signaling complex. Nat. Neurosci. 7, 221-228.

Mills, J. C., Stone, N. L., Erhardt, J., and Pittman, R. N. (1998). Apoptotic membrane blebbing is regulated by myosin light chain phosphorylation. J. Cell Biol. 140, 627-636.

Monnier, P. P., Sierra, A., Schwab, J. M., Henke-Fahle, S., and Mueller, B.
K. (2003). The Rho/ROCK pathway mediates neurite growth-inhibitory activity associated with the chondroitin sulfate proteoglycans of the CNS glial scar. Mol. Cell. Neurosci. 22, 319-330.

Mueller, B. K., Mack, H., and Teusch, N. (2005). Rho kinase, a promising drug target for neurological disorders. Nat. Rev. Drug Discov. 4, 387-398.

Nakagawa, O., Fujisawa, K., Ishizaki, T., Saito, Y., Nakao, K., and Narumiya, S. (1996). ROCK-I and ROCKII, two isoforms of Rho-associated coiled-coil forming protein serine/threonine kinase in mice. FEBS Lett. 392, 189-193.

Ng, J., and Luo, L. (2004). Rho GTPases regulate axon growth through convergent and divergent signaling pathways. Neuron 44, 779-793.

Nishio, Y., Koda, M., Kitajo, K., Seto, M., Hata, K., Taniguchi, J., Moriya, H., Fujitani, M., Kubo, T., and Yamashita, T. (2006). Delayed treatment with Rho-kinase inhibitor does not enhance axonal regeneration or functional recovery after spinal cord injury in rats. Exp. Neurol. 200, 392-397.

Noma, K., Rikitake, Y., Oyama, N., Yan, G., Alcaide, P., Liu, P. Y., Wang, H. Ahl, D., Sawada, N., Okamoto, R., Hiroi, Y., Shimizu, K., Luscinskas, F. W., Sun, J., and Liao, J. K. (2008). ROCK1 mediates leukocyte recruitment and neointima formation following vascular injury. J. Clin. Invest. 118, 1632-1644.

Park, J. H., Arakawa-Takeuchi, S., Jinno, S., and Okayama, H. (2011). Rho-associated kinase connects a cell cycle-controlling anchorage signal to the mammalian target of rapamycin pathway. J. Biol. Chem. 286, 23132-23141.

Park, K. K., Liu, K., Hu, Y., Kanter, J. L., and He,Z. (2010). PTEN/mTOR and axon regeneration. Exp. Neurol. 223, 45-50.

Park, K. K., Liu, K., Hu, Y., Smith, P. D., Wang, C., Cai, B., Xu, B., Connolly, L., Kramvis, I., Sahin M., and He, Z. (2008). Promoting axon regeneration in the adult CNS by modulation of the PTEN/mTOR pathway. Science 322, 963-966.

Pasterkamp, R. J., Giger, R. J., and Verhaagen, J. (1998). Regulation of semaphorin III/collapsin-1 gene expression during peripheral nerve regeneration. Exp. Neurol. 153, 313-327.

Pearce, L. R., Komander, D., and Alessi, D. R. (2010). The nuts and bolts of AGC protein kinases. Nat. Rev. Mol. Cell Biol. 11, 9-22. 
Piazzolla, D., Meissl, K., Kucerova, L., Rubiolo, C., and Baccarini, M. (2005). Raf- 1 sets the threshold of Fas sensitivity by modulating Rokalpha signaling. J. Cell Biol. 171, 1013-1022.

Qiu, J., Cafferty, W. B., McMahon, S. B., and Thompson, S. W. (2005). Conditioning injury-induced spinal axon regeneration requires signal transducer and activator of transcription 3 activation. J. Neurosci. 25, 1645-1653.

Riento, K., and Ridley, A. J. (2003). Rocks: multifunctional kinases in cell behaviour. Nat. Rev. Mol. Cell Biol. 4, 446-456.

Rikitake, Y., Kim, H. H., Huang, Z., Seto, M., Yano, K., Asano, T., Moskowitz, M. A., and Liao, J. K. (2005). Inhibition of Rho kinase (ROCK) leads to increased cerebral blood flow and stroke protection. Stroke 36, 2251-2257.

Ross-Macdonald, P., de Silva, H., Guo, Q., Xiao, H., Hung, C. Y., Penhallow, B., Markwalder, J., He, L., Attar, R. M., Lin, T. A., Seitz, S., Tilford, C., Wardwell-Swanson, J., and Jackson, D. (2008). Identification of a nonkinase target mediating cytotoxicity of novel kinase inhibitors. Mol. Cancer Ther. 7, 3490-3498.

Sandvig, A., Berry, M., Barrett, L. B., Butt, A., and Logan, A. (2004). Myelin-, reactive glia-, and scarderived CNS axon growth inhibitors: expression, receptor signaling, and correlation with axon regeneration. Glia 46, 225-251.

Schirok, H., Kast, R., Figueroa-Perez, S., Bennabi, S., Gnoth, M. J., Feurer, A., Heckroth, H., Thutewohl, M., Paulsen, H., Knorr, A., Hutter, J., Lobell, M., Munter, K., Geiss, V., Ehmke, H., Lang, D., Radtke, M., Mittendorf, J., and Stasch, J. P. (2008). Design and synthesis of potent and selective azaindole-based Rho kinase (ROCK) inhibitors. Chem. Med. Chem. 3, 1893-1904.

Schueller, O., Tong, W., Ferkany, J. W., and Sweetnam, P. (2006). Abstract 1216: selective ROCK 2 inhibition attenuates arterial plaque formation in an ApoE knockout mouse model. Circulation 114, 228-b.

Schwab, M. E. (2010). Functions of Nogo proteins and their receptors in the nervous system. Nat. Rev. Neurosci. 11, 799-811.

Scott, R. W., Hooper, S., Crighton, D., Li, A., Konig, I., Munro, J., Trivier, E., Wickman, G., Morin, P., Croft, D. R., Dawson, J., Machesky, L., Anderson, K. I., Sahai, E. A., and Olson, M. F. (2010). LIM kinases are required for invasive path generation by tumor and tumor-associated stromal cells. J. Cell Biol. 191, 169-185.

Sebbagh, M., Hamelin, J., Bertoglio, J., Solary, E., and Breard, J. (2005). Direct cleavage of ROCK II by granzyme B induces target cell membrane blebbing in a caspaseindependent manner. J. Exp. Med. 201, 465-471.

Sebbagh, M., Renvoize, C., Hamelin, J., Riche, N., Bertoglio, J., and Breard, J. (2001). Caspase-3-mediated cleavage of ROCK I induces MLC phosphorylation and apoptotic membrane blebbing. Nat. Cell Biol. 3, 346-352.

Shamah, S. M., Lin, M. Z., Goldberg, J. L., Estrach, S., Sahin, M., Hu, L., Bazalakova, M., Neve, R. L., Corfas, G., Debant, A., and Greenberg, M. E. (2001). EphA receptors regulate growth cone dynamics through the novel guanine nucleotide exchange factor ephexin. Cell 105, 233-244.

Sheikh, A. M., Nagai, A., Ryu, J. K., McLarnon, J. G., Kim, S. U., and Masuda, J. (2009). Lysophosphatidylcholine induces glial cell activation: role of rho kinase. Glia 57, 898-907.

Shi, J., and Wei, L. (2007). Rho kinase in the regulation of cell death and survival. Arch. Immunol. Ther. Exp. (Warsz) 55, 61-75.

Shibuya, M., Hirai, S., Seto, M., Satoh, S., and Ohtomo, E. (2005). Effects of fasudil in acute ischemic stroke: results of a prospective placebocontrolled double-blind trial. J. Neurol. Sci. 238, 31-39.

Shin, H. K., Salomone, S., Potts, E. M., Lee, S. W., Millican, E., Noma, K., Huang, P. L., Boas, D. A., Liao, J. K., Moskowitz, M. A., and Ayata, C. (2007). Rho-kinase inhibition acutely augments blood flow in focal cerebral ischemia via endothelial mechanisms. J. Cereb. Blood Flow Metab. 27, 998-1009.

Sun, X., Minohara, M., Kikuchi, H., Ishizu, T., Tanaka, M., Piao, H., Osoegawa, M., Ohyagi, Y., Shimokawa, H., and Kira, J. (2006). The selective Rho-kinase inhibitor Fasudil is protective and therapeutic in experimental autoimmune encephalomyelitis. J. Neuroimmunol. 180, 126-134.

Sung, J. K., Miao, L., Calvert, J. W., Huang, L., Louis Harkey, H., and Zhang, J. H. (2003). A possible role of RhoA/Rho-kinase in experimental spinal cord injury in rat. Brain Res. 959, 29-38.

Suzuki, Y., Shibuya, M., Satoh, S., Sugiyama, H., Seto, M., and Takakura, K. (2008). Safety and efficacy of fasudil monotherapy and fasudil-ozagrel combination therapy in patients with subarachnoid hemorrhage: sub-analysis of the post-marketing surveillance study. Neurol. Med. Chir. (Tokyo) 48, 241-247; discussion 247-248.

Takesono, A., Heasman, S. J., WojciakStothard, B., Garg, R., and Ridley, A. J. (2010). Microtubules regulate migratory polarity through Rho/ROCK signaling in T cells. PLoS ONE 5, e8774. doi:10.1371/journal.pone.0008774

Tanihara, H., Inatani, M., Honjo, M. Tokushige, H., Azuma, J., and Araie, M. (2008). Intraocular pressurelowering effects and safety of topical administration of a selective ROCK inhibitor, SNJ-1656, in healthy volunteers. Arch. Ophthalmol. 126, 309-315.

Teraishi, K., Kurata, H., Nakajima, A., Takaoka, M., and Matsumura, Y. (2004). Preventive effect of Y-27632, a selective Rho-kinase inhibitor, on ischemia/reperfusion-induced acute renal failure in rats. Eur. J. Pharmacol. 505, 205-211.

Thumkeo, D., Keel, J., Ishizaki, T., Hirose, M., Nonomura, K., Oshima, H., Oshima, M., Taketo, M. M., and Narumiya, S. (2003). Targeted disruption of the mouse rho-associated kinase 2 gene results in intrauterine growth retardation and fetal death. Mol. Cell. Biol. 23, 5043-5055.

Tura, A., Schuettauf, F., Monnier, P. P., Bartz-Schmidt, K. U., and HenkeFahle, S. (2009). Efficacy of Rhokinase inhibition in promoting cell survival and reducing reactive gliosis in the rodent retina. Invest. Ophthalmol. Vis. Sci. 50, 452-461.

Wang, K. C., Kim, J. A., Sivasankaran, R., Segal, R., and He, Z. (2002). P75 interacts with the Nogo receptor as a co-receptor for Nogo, MAG and OMgp. Nature 420, 74-78.

Wang, Y., Zheng, X. R., Riddick, N., Bryden, M., Baur, W., Zhang, X., and Surks, H. K. (2009). ROCK isoform regulation of myosin phosphatase and contractility in vascular smooth muscle cells. Circ. Res. 104, 531-540.

Wang, Y. H., Wang, D. W., Wu, N., Wang, Y., and Yin, Z. Q. (2011). Alpha-crystallin promotes rat axonal regeneration through regulation of RhoA/Rock/Cofilin/MLC signaling pathways. J. Mol. Neurosci. doi: 10.1007/s12031-011-9537-z. [Epub ahead of print].

Wang, Y. X., da Cunha, V., MartinMcNulty, B., Vincelette, J., Li, W., Choy, D. F., Halks-Miller, M., Mahmoudi, M., Schroeder, M., Johns, A., Light, D. R., and Dole, W. P. (2005a). Inhibition of Rho-kinase by fasudil attenuated angiotensin II-induced cardiac hypertrophy in apolipoprotein E deficient mice. Eur. J. Pharmacol. 512, 215-222.

Wang, Y. X., Martin-McNulty, B., da Cunha, V., Vincelette, J., Lu, X., Feng, Q., Halks-Miller, M., Mahmoudi, M., Schroeder, M., Subramanyam, B., Tseng, J. L., Deng, G. D., Schirm, S., Johns, A., Kauser, K., Dole, W. P. and Light, D. R. (2005b). Fasudil, a Rho-kinase inhibitor, attenuates angiotensin II-induced abdominal aortic aneurysm in apolipoprotein E-deficient mice by inhibiting apoptosis and proteolysis. Circulation 111, 2219-2226.

Wettschureck, N., and Offermanns, S. (2002). Rho/Rho-kinase mediated signaling in physiology and pathophysiology. J. Mol. Med. 80, 629-638. Wu, D., Yang, P., Zhang, X., Luo, J., Haque, M. E., Yeh, J., Richardson, P. M., Zhang, Y., and Bo, X. (2009). Targeting a dominant negative rho kinase to neurons promotes axonal outgrowth and partial functional recovery after rat rubrospinal tract lesion. Mol. Ther. 17, 2020-2030.

Yamashita, K., Kotani, Y., Nakajima, Y., Shimazawa, M., Yoshimura, S., Nakashima, S., Iwama, T., and Hara, H. (2007). Fasudil, a Rho kinase (ROCK) inhibitor, protects against ischemic neuronal damage in vitro and in vivo by acting directly on neurons. Brain Res. 1154, 215-224.

Yang, N., Higuchi, O., Ohashi, K., Nagata, K., Wada, A., Kangawa, K., Nishida, E., and Mizuno, K. (1998). Cofilin phosphorylation by LIMkinase 1 and its role in Rac-mediated actin reorganization. Nature 393, 809-812.

Yiu, G., and He, Z. (2006). Glial inhibition of CNS axon regeneration. Nat. Rev. Neurosci. 7, 617-627.

Yoneda, A., Multhaupt, H. A., and Couchman, J. R. (2005). The Rho kinases I and II regulate different aspects of myosin II activity. J. Cell Biol. 170, 443-453.

Yu, J. Z., Ding, J., Ma, C. G., Sun, C. H., Sun, Y. F., Lu, C. Z., and Xiao, B. G. (2010). Therapeutic potential of experimental autoimmune encephalomyelitis by Fasudil, a Rho kinase inhibitor. J. Neurosci. Res. 88, 1664-1672.

Zhang, L., Valdez, J. M., Zhang, B., Wei, L., Chang, J., and Xin, L. (2011). ROCK inhibitor Y-27632 suppresses dissociation-induced apoptosis of murine prostate stem/progenitor cells and increases their cloning efficiency. PLoS ONE 6, el8271. doi:10.1371/journal.pone.0018271

Zhang, Z., Ottens, A. K., Larner, S. F., Kobeissy, F. H., Williams, M. L., Hayes, R. L., and Wang, K. K. (2006). 
Direct Rho-associated kinase inhibition [correction of inhibiton] induces cofilin dephosphorylation and neurite outgrowth in PC-12 cells. Cell. Mol. Biol. Lett. 11, 12-29.

Zhao, J., Zhou, D., Guo, J., Ren, Z., Zhou, L., Wang, S., Xu, B., and Wang, R. (2006). Effect of fasudil hydrochloride, a protein kinase inhibitor, on cerebral vasospasm and delayed cerebral ischemic symptoms after aneurysmal subarachnoid hemorrhage. Neurol. Med. Chir. (Tokyo) 46, 421-428.

Zhou, Z., Meng, Y., Asrar, S., Todorovski, Z., and Jia, Z. (2009). A critical role of Rho-kinase ROCK2 in the regulation of spine and synaptic function. Neuropharmacology 56, 8-89.

Conflict of Interest Statement: The authors declare that the research was conducted in the absence of any commercial or financial relationships that could be construed as a potential conflict of interest.

Received: 29 August 2011; paper pending published: 20 September 2011; accepted: 16 October 2011; published online: 03 November 2011.

Citation: Tönges L, Koch J-C, Bähr $M$ and Lingor $P$ (2011) ROCKing regeneration: Rho kinase inhibition as molecular target for neurorestoration. Front. Mol. Neurosci. 4:39. doi: 10.3389/fnmol.2011.00039

Copyright () 2011 Tönges, Koch, Bähr and Lingor. This is an open-access article subject to a non-exclusive license between the authors and Frontiers Media SA, which permits use, distribution and reproduction in other forums, provided the original authors and source are credited and other Frontiers conditions are complied with. 